\title{
Pengendalian Kualitas Multivariat pada Proses Produksi Rokok W di PT. I
}

\author{
Zuyyin Inesa Pratiwi dan Diaz Fitra Aksioma \\ Departemen Statistika, Fakultas Matematika Komputasi dan Sains Data, \\ Institut Teknologi Sepuluh Nopember (ITS) \\ e-mail:diaz_fa@statistika.its.ac.id
}

\begin{abstract}
Abstrak-Kualitas produk merupakan kunci untuk dapat bersaing dalam dunia industri. Penerapan pengendalian kualitas dengan ilmu statistika dalam peningkatan kualitas merupakan hal yang disarankan menurut metodologi six sigma. Diagram kendali merupakan metode yang digunakan untuk mengetahui variabilitas dan rata-rata proses produksi suatu produk. Penelitian ini mengambil permasalahan pengendalian kualitas produksi rokok WK di PT. I yang diproduksi secara manual. Karakteristik kualitas yang digunakan berat rokok dan pressure drop yang saling berhubungan sehingga analisis yang akan digunakan adalah diagram kendali Moving Range dan Individual, diagram kendali $M$ dan $T^{2}$ Hotelling untuk mengetahui kebaikan proses produksi rokok WK. Hasil dari analisis diagram kendali $M$ dan $T^{2}$ Hotelling variabilitas dan ratarata proses terkendali secara statistik. Kapabilitas proses menunjukkan bahwa presisi proses telah baik tetapi target (akurasi) belum tepenuhi. diakibat oleh berat bahan baku yang berkurang. Selain dari bahan baku, penyebab lain yaitu usia, kondisi ruang kerja yang tidak kondusif, alat tidak diganti berkala, dan metode inspeksi sederhana.
\end{abstract}

Kata Kunci-Diagram Ishikawa,Diagram KendaliIndividual, Diagram Kendali M, Diagram KendaliMoving Range, Diagram Kendali $\mathbf{T}^{2}$ Hotelling, Kapabilitas Proses, Rokok W.

\section{PENDAHULUAN}

$\mathrm{P}$ ERKEMBANGAN perusahaan rokok di Indonesia sangat pesat, dimana pendapatan negara dari sektor industri rokok sangat besar. Terdapat pungutan negara dari Cukai, Pajak Pertambahan Nilai (PPN), Pajak Penghasilan (PPh), dan Pajak Daerah Restribusi Daerah (PDRD). Keistimewaan industri rokok selain dari sudut pandang pendapatan negara adalah penyerapan tenaga kerja yang besar. Menurut Kementrian Pertanian pada tahun 2017 menunjukkan jumlah tenaga keja yang bekerja sebagai tenaga kerja untuk industri rokok sudah hampir 3 juta kepala rumah tangga. Selain jumlah tenaga kerja untuk industri rokok juga terdapat pekerja advertising dan medianya. Dari berbagai sudut pandang inilah alasan mengapa industri rokok masih tetap jaya. Salah satu perusahaan rokok adalah PT. I.

PT. I merupakan perusahaan rokok yang memproduksi 2 macam rokok kretek yaitu, Sigaret Kretek Tangan (SKT) dan Sigaret Kretek Mesin (SKM). Salah satu produk yang banyak diminati oleh konsumen dari SKT adalah rokok W. Semakin banyaknya permintaan pasar mengenai produk $\mathrm{W}$, maka diharapkan PT. Imemproduksi lebih banyak produk yang sesuai spesifikasi. Sehingga PT. I perlu untuk terus meningkatkan kualitas produknya.

Salah satu alat yang dapat digunakan untuk pengendaliankualitas secara statistik adalah diagram kendali.
Terdapat dua jenisdiagram kendali yaitu diagram kendali univariate dan diagramkendali multivariate. Diagram kendali univarite digunakan untuksatu karakteristik kualitas sedangkan diagram kendali multivariate digunakan untuk dua atau lebih karakteristik kualitas [1]. Dalam penelitian rokok W memiliki beberapa karakteristik kualitas yaitu berat rokok, dimeter pen, diameter kepala dan pressure drop. Karakteristik berat rokok dan pressure drop dimana keduanya merupakan karakteristik kualitas yang diduga memiliki hubungan linier. Pengendalian kualitas di PT. I sementara ini hanya menggunakan pengecekan produk dibandingkan dengan batas spesifikasi yang telah ditentukan. Oleh karena itu, dalam penelitian ini metode yang digunakan adalah diagram kendali Individual dan Moving Range sertadiagramkendaliM dan diagram kendali $\mathrm{T}^{2}$ Hotelling. Penelitian ini di harapkan dapat menjadibahan evaluasi dan masukan untuk PT. Ipadapengendalian kualitas produk yang di produksi khususnya pada produk rokok W. Sehingga dalam waktu mendatang PT. Idapat meningkatkan kualitas dari produk yang dihasilkan khususnya produk W.

Penelitian sebelumnya dilakukan oleh Fitria (2014) hasil analisis yang diperolehpengontrolan proses produksi kertas jenis NewsprintPaper di PT.Adiprima Suraprinta ditemukan data keluar dari batas kendalikarena faktor lingkungan, bahan, mesin, operatormaupun metode [2]. Penelitian sebelumnya dilakukan oleh Mawardi (2016) mengenai pengendalian kualitas statistik proses produksi diplomat Mild di PT. Gelora Djaja menggunakan diagram kendaliGeneralized Variance dan $\mathrm{T}^{2}$ Hotelling diperoleh hasil bahwa penyebab terjadinya proses produksi diluar batas kendali disebabkan karena bahan baku yang digunakan keluar dari spesifikasi, operator sering berganti, suhu ruangan terlalu dingin, luas ruangan terlalu sempit, pengawasan sistem operator kurang, dan mesin yang digunakan cukup tua sehingga sering mengalami gagal operasi [3]. Penelitian sebelumnnya juga dilakukan oleh Ziarieputri (2017) mengenai pengendalian kualitas pada produk herbisida pupuk Sidafos 480SL di PT. Petrosida Gresik dengan diagram kendaliT ${ }^{2}$ Hotelling dan Multivariate Exponentially Weighted Moving Average (MEWMA) menunjukkan bahwa proses produksi Sidafos 480SL belum terkendali secara statistik, baik dalam variabilitas maupun dalam rata-rata proses. Kapabilitas proses produksi Sidafos 480SL belum kapabel [4].

\section{TINJAUAN PUSTAKA}

\section{A. Uji Dependensi}

Variabel $\mathrm{X}_{1 .,}, \mathrm{X}_{2 .}, \mathrm{X}_{3, \ldots}, \mathrm{X}_{\mathrm{p}}$ dikatakan bersifat saling bebas (independen) jika matriks korelasi antar variabel membentuk 
matriks identitas [5]. Uji dependensiantar variabel ini dapat dilakukan dengan uji Bartlett Sphericity sebagai berikut.

$\mathrm{H}_{0}: \boldsymbol{\rho}=\mathbf{I}$ (tidak terdapat korelasi antar variabel)

$\mathrm{H}_{1}: \boldsymbol{\rho} \neq \mathbf{I}$ (terdapat korelasi antar variabel)

Statistika uji :

$$
\chi_{\text {hitung }}^{2}=-\left\{n-1-\frac{2 p+5}{6}\right\} \ln |\mathbf{R}|
$$

Keterangan:

$n$ : Banyak data pengamatan

$p$ : Banyak variabel yang digunakan

R : Matriks korelasi

Daerah kritis yang digunakan dalam uji BartlettSphericity ini adalah $\mathrm{H}_{0}$ ditolak jika $\chi_{\text {hitung }}^{2}>\chi_{\alpha, \frac{1}{2} p(p-1)}^{2}$ atau $p$-value $<$

a. Dengan demikian, kesimpulan yang dapat diambil adalah matriks korelasi bukan merupakan matriks identitas, yang berarti bahwa terdapat hubungan antar variabelnya.

\section{B. Uji Distribusi Normal Multivariat}

Salah satu hal yang harus diperiksapada pengendalian kualitas menggunakan diagram kendali multivariat adalah distribusi normal multivariat. Variabel $\mathrm{X}_{1}, \mathrm{X}_{2}, \ldots, \mathrm{X}_{\mathrm{p}}$ dikatakan berdistribusi normal multivariat dengan parameter $\boldsymbol{\mu}$ dan $\sum$ jika mempunyai probability density function berikut ini [5].

$$
f(x)=\frac{1}{(2 \pi)^{p / 2} \mid \Sigma^{1 / 2}} e^{-\frac{1}{2}(x-\mu)^{\prime} \Sigma^{-1}(x-\mu)}
$$

dimana:

$\boldsymbol{\mu}$ : vektor rata-rata

$\sum$ : matrik varians kovarians populasi

$\mathrm{p}$ : banyaknya karakteristik kualitas

Pengujian normal multivariat menggunakan SaphiroWilk'sdengan hipotesis berikut ini.

$\mathrm{H}_{0}$ :Data berdistribusi normal multivariat

$\mathrm{H}_{1}$ : Data tidak berdistribusi normal multivariat

Statistik Uji:

$$
W^{*}=\frac{1}{p} \sum_{j=1}^{p} W_{z_{j}}
$$

dimana $W_{z_{j}}$ merupakan titik koordinat ke-j dari observasi yang telah ditransformasi $Z_{j l}, \ldots, Z_{j n}, j=1,2, \ldots, p . \mathrm{H}_{0}$ akan ditolak jika nilai $W^{*}<C_{\alpha ; n ; p}$ yang berarti bahwa data tidak berdistribusi normal multivariate [6].

\section{Diagram KendaliIndividual dan Moving Range}

Pengendalian kualitas secara statistik adalah sebuah tehnik yang membantu untuk mendeteksi proses yang tidak normal dalam suatu proses produksi yang disebabkan oleh hal-hal tertentu. Pengendalian kualitas statistik memiliki asumsi standard yaitu bahwa data yang digunakan berdistribusi normal. Dikarenakan adanya perilaku yang dinamis, maka asumsi ini tidak selalu terpenuhi [7]. Pengendalian kualitas statistik dapat dilakukan secara univariat dan univariat, baik untuk pengamatan subgrup atau individu.
Pengamatan individu biasanya terjadi apabila tingkat produksi rendah, atau tes yang dilakukan pada produk bersifat merusak. Diagram kendali Moving Range adalah diagram kendali univariat yang digunakan untuk memonitoring variabilitas proses. Nilai yang digunakan pada diagram kendali ini adalah selisih antar pengamatan dengan garis tengah dan batas kendali sebagai berikut.

$$
\begin{aligned}
& \text { BKA }=D_{4} \bar{R} \\
& \text { Nilai Tengah }=\bar{R} \\
& \text { BKB }=D_{3} \bar{R}
\end{aligned}
$$

Dengan $\mathrm{n}$ (banyak pengamatan yang digunakan dalam Moving Range) $=2$, maka $D_{4}=3,267$ dan $D_{3}=0$. Selanjutnya diagram kendali individual digunakan untuk memonitoring rata-rata proses. Nilai yang digunakan pada diagram kendali ini adalah nilai pengamatan dengan garis tengah dan batas kendali sebagai berikut.

$$
\begin{aligned}
& \mathrm{BKA}=\bar{x}+3 \frac{\bar{R}}{d_{2}} \\
& \text { Nilai Tengah }=\bar{x} \\
& \mathrm{BKB}=\bar{x}-3 \frac{\bar{R}}{d_{2}}
\end{aligned}
$$

\section{Diagram Kendali $M$}

Diagram kendali $\mathrm{M}$ dapat digunakan untuk memonitor variabilitas proses secara multivariat untuk pengamatan individu yang didasarkan pada successive difference [8]. Successive difference yaitu selisih antar vektor pengamatan secaraberturut-turut dan digunakan dalam menghitung nilai statistiknya dengan menggunakan rumus $x_{i+1}-x_{i}$ dan diperoleh matriks Vyang berdistribusi $\mathrm{N}_{\mathrm{p}}(0,2 \boldsymbol{\Sigma})$ sebagai berikut.

$$
\mathbf{V}=\left[\begin{array}{c}
v_{1}^{\prime} \\
v_{2}^{\prime} \\
\vdots \\
v_{n-1}^{\prime}
\end{array}\right]=\left[\begin{array}{c}
\left(x_{2}-x_{1}\right)^{\prime} \\
\left(x_{3}-x_{2}\right)^{\prime} \\
\vdots \\
\left(x_{n}-x_{n-1}\right)^{\prime}
\end{array}\right]
$$

Matriks Vyang diperoleh dan berdistribusi $\mathrm{N}_{\mathrm{p}}(0,2 \boldsymbol{\Sigma})$ jika dikalikan dengan $\frac{1}{\sqrt{2}}$ maka akan menjadi $\frac{1}{\sqrt{2}} \mathbf{W}$ yang bedistribusi $\mathrm{N}_{\mathrm{p}}(0, \boldsymbol{\Sigma})$. Apabila diketahui $C C^{\prime}=\boldsymbol{\Sigma}$ dimana $\mathbf{C}$ adalah matriks non-singular atau determinan tidak sama dengan nol berukuran mxm dan misal.

$$
\begin{gathered}
\mathbf{U}=\frac{1}{\sqrt{2}} \mathbf{C}^{-1} \mathbf{V} \\
\mathbf{U}=\frac{1}{\sqrt{2}} \mathbf{C}^{-1}\left(x_{i+1}-x_{i}\right)
\end{gathered}
$$

Maka,

$$
\begin{array}{rl}
\mathbf{U} & \mathbf{U}=\left[\frac{1}{\sqrt{2}} \mathbf{C}^{-1} \mathbf{V}\right]\left[\frac{1}{\sqrt{2}} \mathbf{C}^{-1} \mathbf{V}\right] \\
\mathbf{U}^{\prime} \mathbf{U} & =\frac{1}{2} \mathbf{V}^{\prime}\left(\mathbf{C}^{-1}\right)\left(\mathbf{C}^{-1}\right) \mathbf{V} \\
\mathbf{U}^{\prime} \mathbf{U} & =\frac{1}{2} \mathbf{V}^{\prime} \Sigma^{-1} \mathbf{V} \\
\mathbf{U}^{\prime} \mathbf{U} & =\frac{1}{2}\left(x_{i+1}-x_{i}\right)^{\prime} \Sigma^{-1}\left(x_{i+1}-x_{i}\right)
\end{array}
$$


Dimana $\mathbf{U}^{\prime} \mathbf{U}=\mathbf{M}_{i} \square \chi_{p}^{2}$, sehingga perhitungan statistik dalam diagram kendali $\mathrm{M}$ adalah sebagai berikut.

$$
\mathbf{M}_{i}=\frac{1}{2}\left(x_{i}-x_{i-1}\right)^{\prime} \Sigma^{-1}\left(x_{i}-x_{i-1}\right), i=2,3, \ldots, n
$$

Dengan menggunakan statistik M yang berdistribusi $\chi_{p}^{2}$ pada Persamaan (9) maka batas diagram kendali $M$ adalah sebagai berikut.

$$
\begin{aligned}
& \mathrm{BKA}=\chi_{p, \alpha / 2}^{2} \\
& \mathrm{BKB}=\chi_{p, 1-\alpha / 2}^{2}
\end{aligned}
$$

\section{E. Diagram Kendali $T^{2}$ Hotelling Individu}

Suatu proses produksi terkadang memiliki karakteristik kualitas yang lebih dari satu, sehingga hal tersebut dinamakan proses produksi yang bersifat multivariate [9]. Diagram kendali $\mathrm{T}^{2}$ Hotelling individu digunakan untuk pengendalian kualitas dengan karakteristik kualitas suatu produk bersifat multivariat dan hanya memiliki 1 subgrup. Jika menggunakan perhitungan kovarians kurang efektif dalam mendeteksi pergeseran vektor rata-rata. Hal tersebut dikarenakan nilai dari matriks varians kovarians belum cukup dekat dengan nilai matriks varians kovarians yang sesungguhnya (bias). Maka digunakan metode Succesive difference (menggunakan selisih dua vektor pengamatan secara berurutan) untuk mendapatkan matriks varians kovarian. Successivedifference diperoleh dengan menggunakan persamaan berikut.

$$
\begin{gathered}
\mathbf{V}_{i}=x_{i+1}-x_{i}, i=1,2, \ldots, n-1 \\
\mathbf{V}=\left[\begin{array}{c}
v_{1}^{\prime} \\
v_{2}^{\prime} \\
\vdots \\
v_{n-1}^{\prime}
\end{array}\right]=\left[\begin{array}{c}
\left(x_{2}-x_{1}\right)^{\prime} \\
\left(x_{3}-x_{2}\right)^{\prime} \\
\vdots \\
\left(x_{n}-x_{n-1}\right)^{\prime}
\end{array}\right]
\end{gathered}
$$

Dimana $\mathbf{V}$ merupakan vektor selisih antara vektor data ke-i dan vektor data ke $i+1$. Kemudian matriks kovarians dapat dihitung dengan menggunakan persamaan berikut.

$$
\mathbf{S}=\frac{1}{2} \frac{\mathbf{V}^{\prime} \mathbf{V}}{(n-1)}
$$

Setelah didapatkan matriks varians kovarians pada Persamaan (13), selanjunya menghitung nilai statistik $\mathrm{T}^{2}$ Hotelling individu dengan persamaan sebagai berikut.

$$
\mathbf{T}^{2}=(\mathbf{x}-\overline{\mathbf{x}})^{\prime} \mathbf{S}^{-\mathbf{1}}(\mathbf{x}-\overline{\mathbf{x}})
$$

Seperti halnya dengan diagram kendali yang lain, pengendalian kualitas secara multivariat dengan diagram kendali $\mathrm{T}^{2}$ Hotelling Individu memiliki batasan kontol untuk fase I sebagai berikut.

$$
\begin{aligned}
& \mathrm{BKA}=\frac{(n-1)^{2}}{n} \beta_{\alpha, p / 2,(n-p-1) / 2} \\
& \mathrm{BKB}=0
\end{aligned}
$$

Keterangan:

$\mathrm{n}=$ banyaknya pengamatan, $i=1,2, \ldots, n$

$\mathrm{p}=$ banyaknya karakteristik kualitas

\section{F. Kapabilitas Proses}

Kapabilitas proses adalah suatu studi keteknikan guna menaksir kemampuan proses. Analisis kemampuan proses merupakan bagian yang sangat penting dari keseluruhan program peningkatan kualitas [9].

Proses dikatakan kapabel jika :

1. Dalam keadaan terkendali

2. Memenuhi batas spesifikasi

3. Tingkat presisi dan akurasi tinggi

Analisis kapabilitas proses untuk data multivariat adalah sebagai berikut [10].

$$
\begin{aligned}
& M C_{P}=\sum_{K=1}^{P} W_{k} C_{P}\left(X_{k}\right) \\
& M C_{P K}=\sum_{K=1}^{P} W_{k} C_{P K}\left(X_{k}\right)
\end{aligned}
$$

Keterangan:

$M C_{P} \quad=$ Tingkat presisi data multivariat

$M C_{P K} \quad=$ Tingkat akurasi data multivariat

$\mathrm{W}_{\mathrm{K}}$ merupakan pembobot dengan $\sum_{K=1}^{P} W_{K}=1$. Presisi adalah ukuran kedekatan antara satu pengamatan dengan pengamatan lain, dan nilai Akurasi adalah ukuran kedekatan hasil pengamatan dengan nilai target.

\section{G. Diagram Ishikawa}

Teknik yang berguna untuk analisis ketidaksesuaian lebih lanjut adalah daigram sebab dan akibat (juga dinamakan diagram tulang ikan atau diagram Ishikawa). Diagram sebab dan akibat digunakan untuk melukiskan dengan jelas berbagai sumber ketidaksesuaian dalam produk dan saling hubungannya. Berguna dalam memusatkan perhatian operator, insinyur produksi, dan pimpinan dalam masalah kualitas. Mengembangkan diagram sebab dan akibat yang baik biasanya memajukan tingkat pemahaman teknologi proses[9].

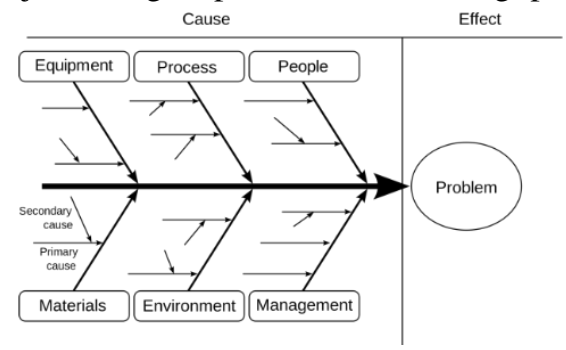

Gambar 1. Diagram Ishikawa.

\section{METODOLOGI PENELITIAN}

\section{A. Variabel Penelitian}

Data penelitian yang digunakan dalam penelitian ini adalah data sekunder yang diperoleh pada produksi bulan Januari hingga Nopember 2017. Data diperoleh dari departemen RnD PT. I pada proses produksi rokok "W". Data terdiri dari variabel berat rokok dan Pressure Drop (PD). Berat rokok adalah berat rokok dari setiap batang, sedangkan pressure drop adalah daya hidup rokok selama dihisap.

$$
\text { Tabel } 1
$$

Variabel Penelitian

\begin{tabular}{ccccc}
\hline \hline Variabel & $\begin{array}{c}\text { Nama } \\
\text { Variabel }\end{array}$ & Satuan & $\begin{array}{c}\text { Batas } \\
\text { Spesifikasi }\end{array}$ & $\begin{array}{c}\text { Definisi } \\
\text { operasional }\end{array}$ \\
\hline $\mathrm{X}_{1}$ & $\begin{array}{c}\text { Berat } \\
\text { Rokok }\end{array}$ & gram & $1,8-2,1$ & $\begin{array}{c}\text { Berat rokok dari } \\
\text { setiap batang }\end{array}$ \\
$\mathrm{X}_{2}$ & $\begin{array}{c}\text { Pressure } \\
\text { Drop }\end{array}$ & mmWG & $72,9-75,4$ & $\begin{array}{c}\text { Daya hidup rokok } \\
\text { selama dihisap }\end{array}$ \\
\hline \hline
\end{tabular}


Proses pengambilan sampel dilakukan dengan cara pengambilan sampel pada tiap batch sebanyak tiga titik yaitu, atas, tengah dan bawah batch. Setelah pengambilan pada tiap titik tersebut maka dicampur dan diambil lagi sebanyak 1 batang rokok. Satu batang rokok inilah yang digunakan sebagai sampel dalam penelitian ini.

Satu per satu batang rokok dimasukkan dalam alat ditimbang dan dinyalakan untuk mengukur daya hidup rokok W selama dihisap. Hasil dari penimbangan dan pengukuran daya hidup rokok selama dihisap yang telah dilakukan selanjutnya diuji menggunakan analisis statistik yaitu diagram kendali untuk mengetahui kebaikan proses produksi rokok W yang telah dilakukan oleh perusahaan.

Satu per satu batang rokok dimasukkan dalam alat ditimbang dan dinyalakan untuk mengukur daya hidup rokok "W" selama dihisap. Hasil dari penimbangan dan pengukuran daya hidup rokok selama dihisap yang telah dilakukan selanjutnya diuji menggunakan analisis statistik yaitu diagram kendali untuk mengetahui kebaikan proses produksi rokok "W" yang telah dilakukan oleh perusahaan.

Tabel 2.

Struktur Data

\begin{tabular}{ccc}
\multicolumn{3}{c}{ Struktur Data } \\
\hline \hline \multirow{2}{*}{ Observasi ke- } & \multicolumn{2}{c}{ Karakteristik Kualitas (k) } \\
\cline { 2 - 3 } & Berat Rokok & Pressure Drop \\
\hline 1 & $\mathrm{x}_{(1) 1}$ & $\mathrm{x}_{(1) 2}$ \\
2 & $\mathrm{x}_{(2) 1}$ & $\mathrm{x}_{(2) 2}$ \\
$\ldots$ & $\ldots$ & $\ldots$ \\
177 & $\mathrm{x}_{(177) 1}$ & $\mathrm{x}_{(177) 2}$ \\
\hline \hline
\end{tabular}

\section{B. Langkah Penelitian}

Langkah analisis yang dilakukan dalam penelitian ini adalah:

1. Melakukan eksplorasidata produksi rokok W

2. Melakukan pengujian dependensi variabel pada data produksi rokok W.

3. Melakukan pengujian distribusi normal multivariat pada data produksi rokok $\mathrm{W}$.

4. Membuat Diagram Individual data produksi rokok W pada masing-masing variabel.

5. Membuat Diagram Moving Range data produksi rokok W pada masing-masing variabel.

6. Membuat Diagram M data produksi rokok W.

7. Membuat Diagram $\mathrm{T}^{2}$ Hotellingdata produksi rokok W.

8. Identifikasi penyebab out of controldan perbaikan.

9. Membuat Diagram Ishikawa

10. Menghitung kapabilitas proses

11. Membuat kesimpulan.

\section{HASIL DAN PEMBAHASAN}

\section{A. Karakteristik Data}

Analisis karakteristik kualitas produk rokok W dapat digambarkan secara ringkas dengan menggunakan statistika deskriptif untuk mengetahui rata-rata, ragam, nilai minimum, dan nilai maksimum dari hasil pengamatan produk rokok $\mathrm{W}$ di
PT. I. Hasil analisis statistika deskriptif dari hasil produksi rokok W dapat dilihat pada Tabel 3.

Tabel 3

Karakteristik Data Dari Karakteristik Kualitas Rokok W

\begin{tabular}{cccrrc}
\hline \hline $\begin{array}{c}\text { Karakteristik } \\
\text { Kualitas }\end{array}$ & $\begin{array}{c}\text { Rata- } \\
\text { rata }\end{array}$ & Ragam & Min & Maks & $\begin{array}{c}\text { Batas } \\
\text { Spesisikasi }\end{array}$ \\
\hline Berat Rokok & 1,9194 & 0,00142 & 1,82 & 2,03 & $1.8-2,1$ \\
PressureDrop & 74,1810 & 49,32100 & 55,10 & 97,20 & $72,5-75,4$ \\
\hline \hline
\end{tabular}

Tabel 3 menunjukkan karakteristik data hasil produksi rokok $\mathrm{W}$ memiliki rata-rata berat rokok dan pressure drop hasil produksi pada bulan Januari hingga Nopember 2017 berada pada spesifikasi atas dan bawah. Variasi dari hasil pengamatan pada spesifikasi pressure drop perlu menjadi perhatian karena terlalu besar. Selain variasi, nilai minimal dan maksimal pressure drop berada di luar batas spesifikasi.

\section{B. Diagram Kendali $M$ dan Diagram Kendali $T^{2} H o t e l l i n g$}

Sebelum dilakukan pengendalian kualiatas menggunakan diagram kendaliM maupun $\mathrm{T}^{2}$ Hotelling terdapat 2 asumsi yang harus terpenuhi yaitu dependensi variabel dan distribusi normal multivariat. Pengujian dependensi variabel menggunakan pearson correlation didapatkan 0,000 nilai $p$ value lebih kecil $\alpha(0,05)$ dan nilai $\mathrm{T}_{\text {hitung }}$ sebesar 6,27 yang lebih besar dari $\mathrm{T}_{\text {tabel }}$ sebesar 2,26 sehingga didapatkan keputusan tolak $\mathrm{H}_{0}$ yang artinya antara berat rokok dan pressure dropmemiliki hubungan.Sedangkan distribusi normal multivariat menggunakan Saphiro Wilk's didapatkan p-value sebesar 0,07801 yang berarti lebih besar dari $\alpha(0,05)$ sehingga dapat disimpulkan data berdistribusi normal multivariat.

Pengendalian kualitas secara statistik menggunakan diagram kendali diawali dengan pengendalian pada variabilitas dan rata-rata proses pada masing-masing variabel. Pada penelitian ini diagram kendaliMoving Range dan Individual(I-MR) yang digunakan untuk mengendalikan variabilitas dan rata-rata proses secara individu.Berikut ini merupakan hasil pengendalian variabilitas proses produksi rokok Wmasing-masing variabel.

Berdasarkan Gambar 2 dan Gambar 3 menunjukkan bahwa terdapat titik yang keluar dari batas pengamatan pada diagram kendali Moving Range maupun Individual, artinya variabilitas proses maupun rata-rata proses belum terkendali secara statistik. Maka evaluasi terhadap variabilitas proses dan ratarata proses perlu dilakukan. Titik-titik pengamatan yang keluar dari batas kendali diindikasikan merupakan outlier pada proses produksi rokok W. Oleh karena itu, titik-titik pengamatan tersebut akan langsung dikeluarkan secara satu per satu. Perbaikan diagram kendali Moving Range variabel berat rokok dilakukan sebanyak 8 kali perbaikan dan pada variabel Pressure Drop sebanyak 6 kali perbaikan. Sedangkan perbaikan diagram Individual pada variabel berat rokok sebanyak 6 kali perbaikan dan pada variabel Pressure Drop sebanyak 1 kali perbaikan. Berikut merupakan hasil pengendalian kualitas menggunakan diagram kendali I-MR. 


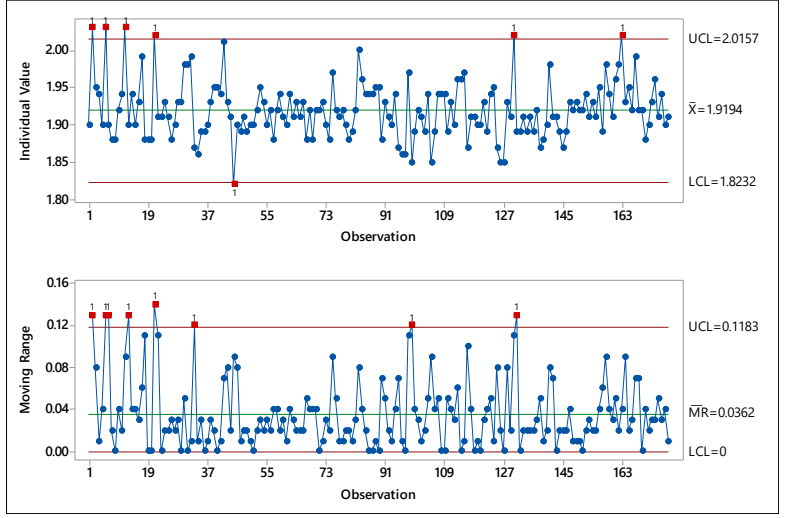

Gambar 2. Diagram kendaliI-MR variabel berat rokok.

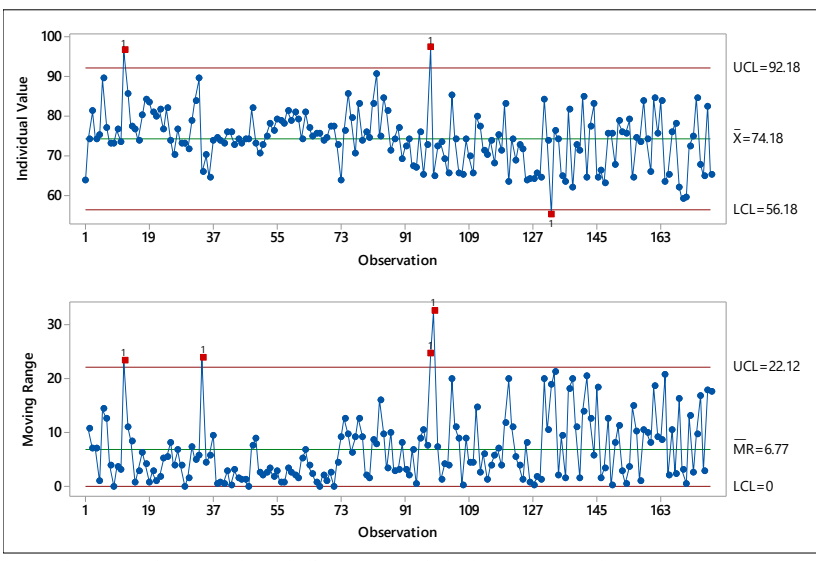

Gambar 3. Diagram kendaliI-MR variabel pressure drop.

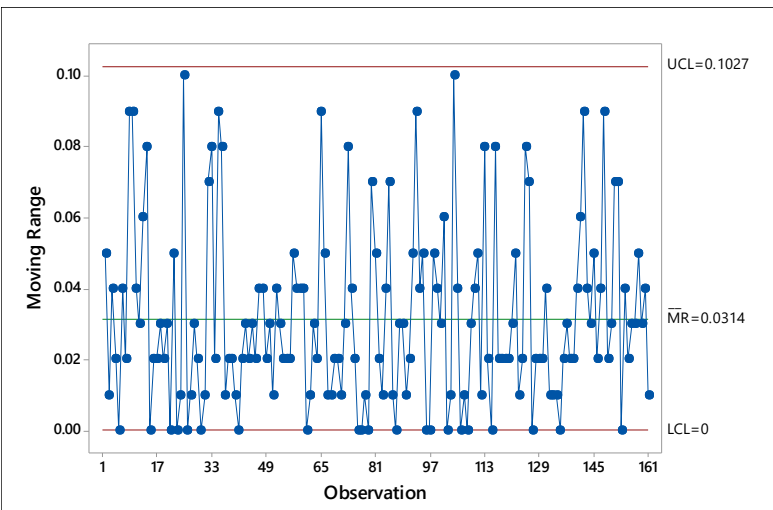

Gambar 4. Diagram Kendali Moving RangeVariabel Berat RokokSetelah perbaikan.

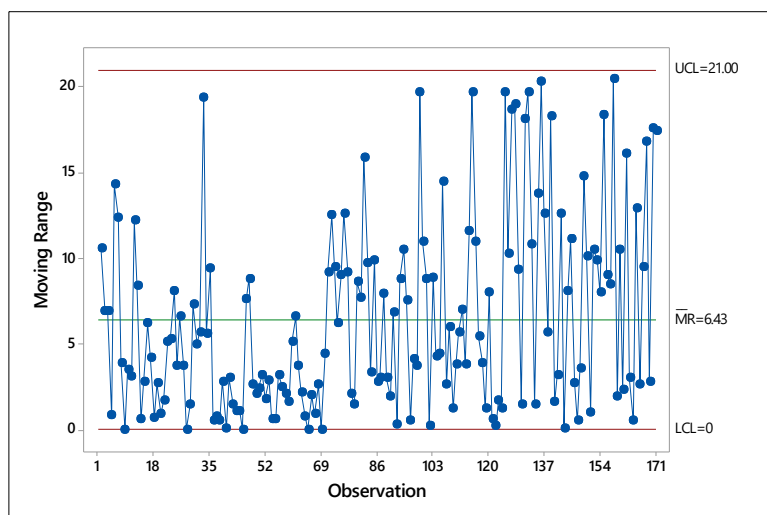

Gambar 5. Diagram Kendali Moving RangeVariabel Pressure DropSetelah perbaikan.

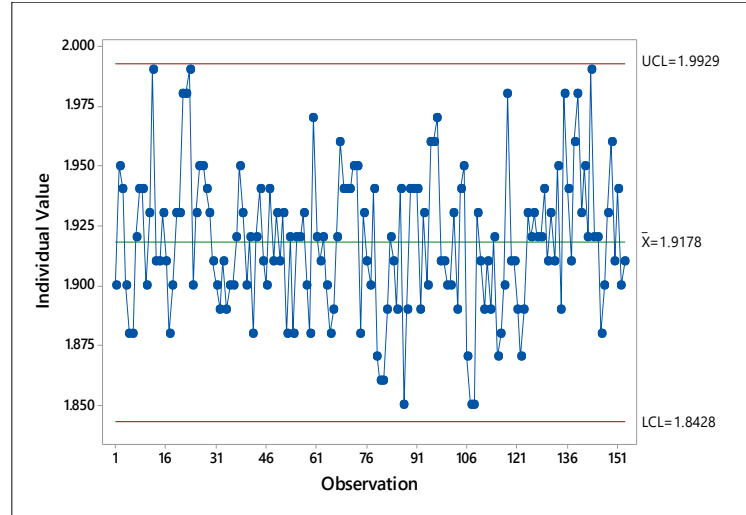

Gambar 6. Diagram kendali individual variabel berat rokok setelah perbaikan.

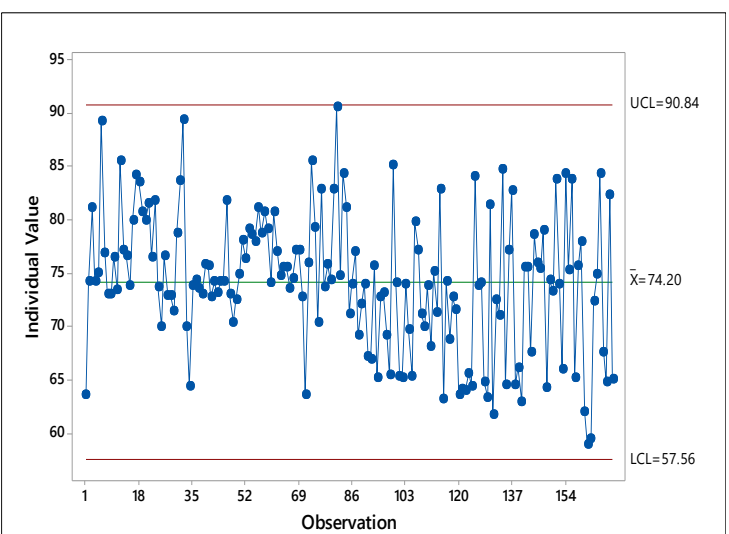

Gambar 7. diagram kendaliindividual variabel pressure drop setelah perbaikan.

Langkah selanjutnya adalah pengendalian kualitas secara multivariat menggunakan diagram kendali $\mathrm{M}$ diagram kendali $\mathrm{T}^{2}$ Hotelling.

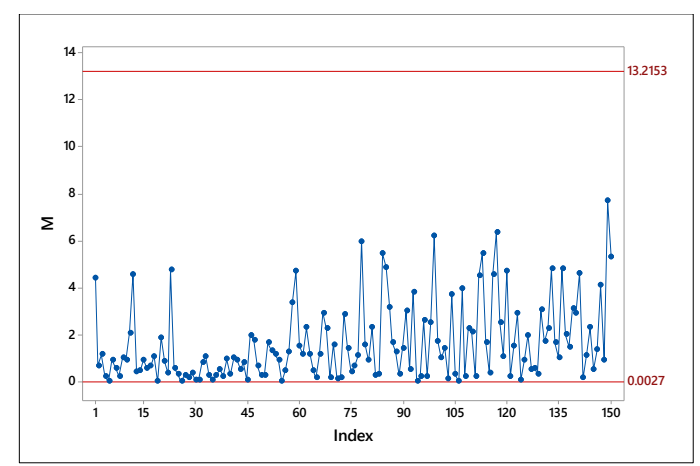

Gambar 8. DiagramKendali M hasil produksi rokok W.

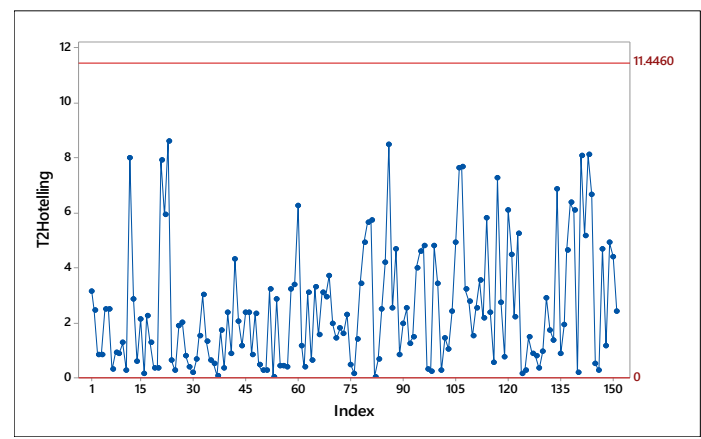

Gambar 3 Diagram Kendali T²Hotelling hasil produksi rokok W. 
Diagram kendali M pada Gambar 8 menunjukkan bahwa variabilitas proses produksi rokok $\mathrm{W}$ telah terkendali. Plotplot M pada Gambar 8 tidak ada yang keluar, masih dalam batas kendali dengan batas kendali atas sebesar 13,2153 dan batas kendali bawah sebesar 0,0027. Hal tersebut mengindikasikan bahwa variabilitas proses produksi rokok $\mathrm{W}$ sudah terkendali secara statistik.

Gambar 9 menunjukkan bahwa rata-rata proses hasil produksi rokok $\mathrm{W}$ terkendali dengan batas kendali atas sebesar 11,4460 dan batas kendali bawah 0 karena plot sudah berada dalam batas kendali.

\section{Identifikasi Penyebab Out of Control dan Diagram Ishikawa}

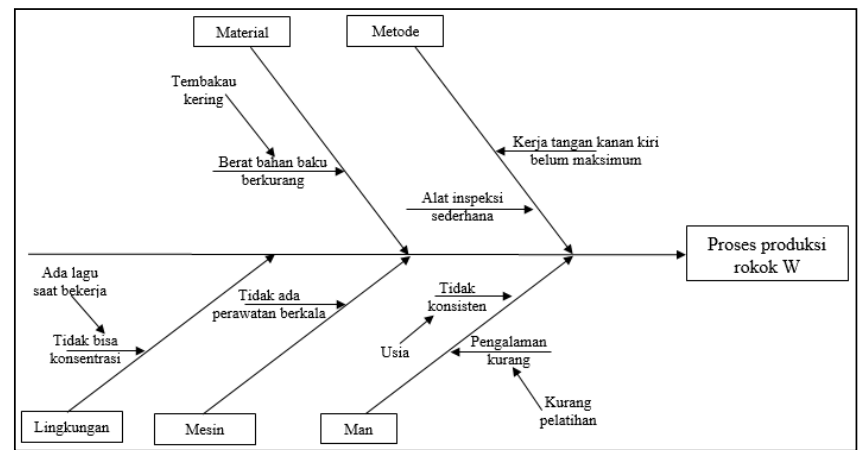

Gambar 4. Diagram Ishikawa Proses Produksi Rokok W.

Dari hasil evaluasi proses yang telah dilakukan, maka PT.I perlu untuk melakukan perbaikan pada produksi rokok W. Untuk dapat melakukan perbaikan, tentunya pihak perusahaan perlu mengetahui faktor-faktor apa saja yang menjadi penyebab terjadinya out of control. Setelah dilakukan penelitian dengan pihak PT. I didapatkan penyebab penyebab dari keadaan out of control. Faktor pertama adalah pada tenaga kerja. Ada beberapa penjelasan mengenai faktor tenaga kerja usia para pekerja beragam mulai dari 17 tahun hingga 50 tahun, mengakibatkan dalam 7 jam kerja konsistensi dan konsentrasi juga beragam, lama bekerja dan pengalaman yang berbeda-beda. Faktor kedua adalah bahan baku utama yaitu tembakau saat proses penyimpanan (overnight) mengalami penurunan berat. Faktor lingkungan kerja pada saat bekerja adanya lagu yang di putar yang gunanya untuk menghibur para pekerja dapat mengurangi konsentrasi. Faktor metode yang digunakan saat bekerja menggunakan tangan kanan dan kiri masih kurang maksimum dan saat inspeksi masih menggunakan alat yang sederhana. Faktor alat yang digunakan tidak dirawat secara berkala, kain kasa yang digunakan untuk melinting rokok masih tetap digunakan hingga terjadi kerusakan.

\section{Analisis Kapabilitas Proses}

Indeks kapabilitas proses digunakan untuk mengetahui apakah proses produksi rokok W di PT. I telah kapabel atau tidak. Kapabilitas proses dapat dilakukan setelah proses terkendali secara statistik. Indeks kapabilitas proses yang digunakan yaitu $C_{p}$ dan $C_{p k}$. Berikut merupakan kapabilitas proses produksi pada masing-masing karakteristik kualitas.
Tabel 4

Indeks Kapabilitas Proses Produksi Rokok W

\begin{tabular}{lcr}
\hline \hline Karakteristik Kualitas & $C_{p}$ & $C_{p k}$ \\
\hline Berat Rokok & 1,99 & 1,57 \\
\hline Pressure Drop & 0,08 & 0,04
\end{tabular}

Tabel 4 menunjukkan bahwa produksi rokok W nilai $C_{p}$ dan $C_{p k}$ berat rokok lebih dari 1 sehingga dikatakan bahwa tingkat presisi maupun akurasi tinggi. Sedangkan tingkat akurasi dan presisi pada Pressure Drop sangat rendah karena nilai kurang dari 1. Berikut merupakan indeks kapabilitas proses produksi rokok $\mathrm{W}$ secara multivariat.

$$
\begin{aligned}
M C_{p} & =\left(w_{1} \times C_{p_{1}}\right)+\left(w_{2} \times C_{p_{2}}\right)=(0,5 \times 1,99)+(0,5 \times 0,08)=1,035 \\
M C_{p k} & =\left(w_{1} \times C_{p k_{1}}\right)+\left(w_{2} \times C_{p k_{2}}\right)=(0,5 \times 1,57)+(0,5 \times 0,04)=0,805
\end{aligned}
$$

Berdasarkan perhitungan manual tersebut nilai indeks kapabilitas proses $M C_{P}$ produksi rokok $\mathrm{W}$ secara multivariat lebih dari 1. Maka dapat disimpulkan bahwa presisi proses produksi rokok $\mathrm{W}$ secara multivariat telah baik namun tidak sesuai target (akurasi) dan tidak kapabel.

\section{KESIMPULAN}

Berdasarkan analisis yang di lakukan diperoleh kesimpulan bahwa, proses produksi rokok $\mathrm{W}$ hanya terkendali secara statistik, dalam variabilitas maupun dalam rata rata proses secara univariat melalui beberapa perbaikan. Sedangkan secara multivariat proses produksi rokok W terkendali secara statistik, dalam variabilitas maupun dalam rata rata proses. Disamping itu apabila di lihat dari identifikasi penyebab out of control dan diagram Ishikawa banyak sekali faktor-faktor yang menyebabkan proses produksi rokok W masih belum terkendali secara statistik. Proses produksi rokok W secara multivariat tidak kapabel. Saran bagi PT. I perlu adanya tinjauan ulang pada faktor-faktor yang menjadi penyebab utama proses tidak terkendali dan melakukan perbaikan proses sehingga akan dicapai kestabilan dan kapabilitas yang baik.

\section{DAFTAR PUSTAKA}

[1] J. Heizer and B. Render, Operations Management, 10th ed. USA: Pearson Education, Inc, 2009.

[2] N. Fitria, "Implementasi Grafik Pengendalian Multivariat T2hotelling Terhadap Kualitas Produk Kertas Newprint di PT. Adiprima Suraprinta," Malang, 2014.

[3] Y. Mawardi, Pengendalian Kualitas Statistik pada Proses Produksi Diplomat Mild di PT Gelora Djaja. Surabaya: ITS Press, 2016.

[4] A. Ziarieputi, Pengendalian Kualitas Produk HerbisidaSidafos 480SL di PT. Petrosida Gresik. Surabaya: ITS Press, 2017.

[5] R. A. Johnson and D. W. Wichern, Applied Multivariate Statistical Analysis. New Jersey: Pearson education, Inc., 2007.

[6] J. Alva and E. Estrada, "A Generalization of Saphiro-Wilk's Test for Multivariate Normality," Commun. Stat. Theory Methods, vol. 38, pp. 1870-1883, 2009.

[7] O. M. Rao, K. Subbaiah, K. Rao, and T. Rao, "Application of Multivariate Control Chart for Movement in Qua-lity of HotmetalCase Study," Int. J. Qual. Res., pp. 623-638, 2013.

[8] M. Khoo and S. Quah, "Multivariate Control Chart ForProcess Dispersion Based On Individual Observations," J. Qual. Eng., vol. 15, no. 4, pp. 639-642, 2003.

[9] D. Montgomery, Introduction to Statistical Quality Control, 6th ed. New York: John Wiley \& Sons Inc, 2009.

[10] S. Raissi, "Multivariate process capability indices on the presence of priority for quality characteristics," J. Ind. Eng. Int., vol. 5, no. 9, pp. 27-36, 2009. 